\title{
Evaluation of Oreochromis niloticus and Tilapia zillii fisheries at Aswan region, River Nile, Egypt
}

\author{
El-Azab E. B. El-Bokhty ${ }^{1}$ and Alaa M. El-Far ${ }^{2}$ \\ 1- Fishing Gear and Methods Laboratory \\ 2- Fish Biology Laboratory, \\ National Institute of Oceanography and Fisheries, Egypt \\ E. Mail: elbokhty@yahoo.com
}

\begin{abstract}
Cichlid fish species dominating River Nile at Aswan region (namely Oreochromis niloticus and Tilapia zillii) were collected from the widespread used trammel nets. Analysis of the length-frequency using (FiSAT) computer program revealed that, the estimated the Von Bertalanffy's growth parameters were $L_{\infty}=25.73 \mathrm{~cm}$ (asymptotic length); $k=0.73$ year $^{-1}$ for $O$. niloticus and $L_{\infty}=19.43 \mathrm{~cm} ; \mathrm{k}=1.4$ year $^{-1}$ for Tilapia zillii . The instantaneous total mortality rate of $O$. niloticus was 3.64 and 5.60 year $^{-1}$ for T. zillii. The estimated natural mortality rate was 1.44 for $O$. niloticus and 2.38 year $^{-1}$ for the second species. The respective fishing mortality rates were 2.2 and 3.22 year $^{-1}$, while their estimated exploitation rates were 0.60 and 0.57 year $^{-1}$. The results indicated that, $O$. niloticus and $T$. zillii fisheries are overexploited. Therefore, it is recommended to decrease the fishing effort in the area of study and increase the mesh size of the inner layer of trammel nets to at least $3 \mathrm{~cm}$ mesh bar to secure profitable fisheries and optimum catch for the future.
\end{abstract}

Keywords: $O$. niloticus, Tilapia zillii, exploitation rate, River Nile, Aswan.

\section{INTRODUCTION}

The fishing industry has a relatively minor direct role in the economy of Egypt, but nevertheless, domestic fish production makes a valuable contribution to the national food supply and to the traditional way of life, in which fish eating plays an important part. Fishing industry is also important for the livelihood of over 65000 fishermen and other people employed full time in related activities (estimated at some 300000), (GAFRD, 2008).

Freshwater fish represent an essential and often irreplaceable source of high quality, and cheap animal protein. Cichlid fish species were found dominating the River Nile and inland lakes. It was found that Oreochromis niloticus and Sarotherodon galilaeus dominated the catch of Lake Nasser (Adam, 2000 and Bishai et al., 2000), while O. niloticus and T. zillii were the dominant species at Rosetta branch (Mahmoud and Mazrouh, 2008 and El- Bokhty and El-Far, 2014).

Various aspects of the biology and fisheries of Cichlid species have been studied in Egypt, e.g. Abdel Azim (1974), Talaat (1979), Ishak et al. (1985), Bayoumi and Khalil (1988), Akel (1989), Dowidar et al. (1990), Abdel-Baky and El-Serafy (1990), Abdel-Aziz et al. (1990), El-Haweet (1991), El-Shazly (1993), Bakhoum (1994, 1995 \& 2002), Essa and Faltas (1997), Abd-Alla and Talaat (2000), Khallaf et al. (2000), Khalifa et al.,(2000), Khallaf (2002), Adam (2004), Eskander (2004), Abaza (2004), Mehanna (2005), El-Bokhty (2006), El-Sayed (2006), El-Sayed and Moharram (2007), and El-Bokhty and El-Far (2014).

Due to the importance of Lake Nasser, several studies have been done, but studies on the River Nile at Aswan area were little. Therefore, the present work aims 
to evaluate the status of fisheries of Oreochromis niloticus and Tilapia zillii in River Nile at Aswan region.

\section{MATERIALS AND METHODS}

The present study is a part from a scientific project, carried out by NIOF, covering the River Nile from Aswan to Alexandria during 2008-2009 entitled "An integrated scientific discipline for protection of the River Nile from pollutants and increasing fishery resources".

Sample collection was taken from the fishing boats working at four stations at Aswan region (Fig. 1) namely; Kima, Aswan city (Al-Markaz), Koum Imbo and Idfu regions during autumn season. Fishing by trammel nets in River Nile is usually carried out by small boats of the third class "Canoe-like faloukas without sails" with mean crew size 2 fishermen from the early dawn to near afternoon. Fishermen employed in fishing use exclusively floating trammel (which are commonly used at the River Nile and its tributaries).

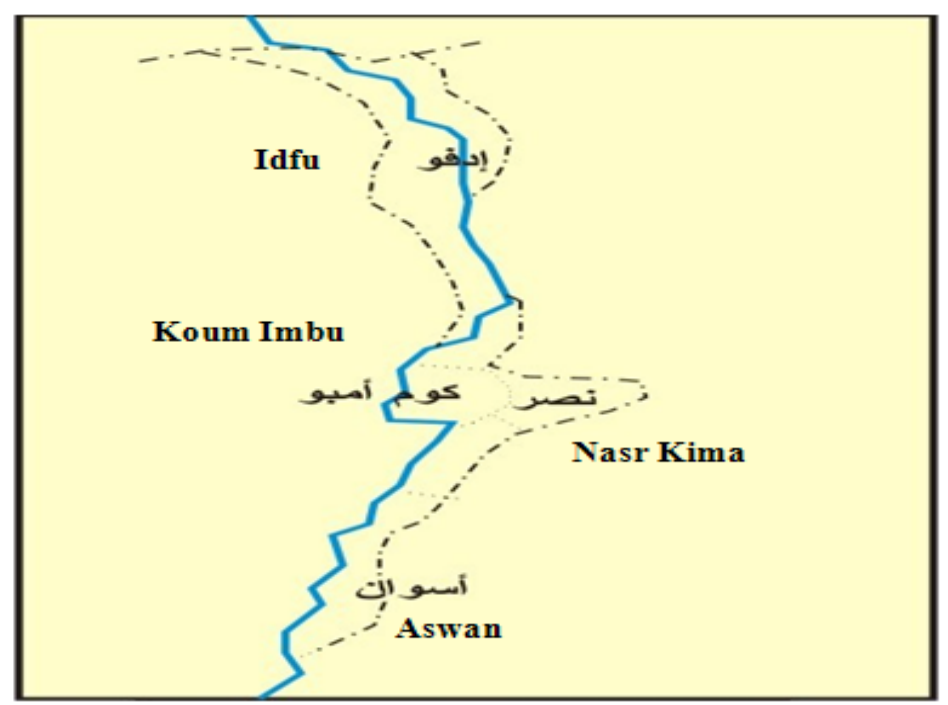

Fig. 1: Location map of Aswan Governorate, Egypt

At the laboratory, fish samples were sorted into species level and for each species was sized to the nearest $\mathrm{cm}$ and weighed to the nearest gram.

The length frequency distributions were analyzed using the appropriate routines and subroutines of the "FiSAT" computer program (Gayanilo, et al., 1997). An estimate of the asymptotic length $\left(\mathrm{L}_{\infty}\right)$ and the growth coefficient $(\mathrm{K})$ were obtained by the method of Wetherall (1986). The parameters were then used as seed values in ELEFAN I routine (Pauly, $1984 \mathrm{a} \& \mathrm{~b}$ ) for estimating the best combination of $\mathrm{L}_{\infty}$ and $\mathrm{K}$.

The instantaneous rate of total mortality $(Z)$ was derived from the length converted catch curve method described by Pauly (1983). The instantaneous rate of natural mortality (M) was computed from the empirical equation of Pauly (1980) considering the mean annual water temperature $25^{\circ} \mathrm{C}$ (Elewa and Latif, 1988). The instantaneous rate of fishing mortality $(\mathrm{F})$ was extracted as $\mathrm{F}=\mathrm{Z}-\mathrm{M}$. The exploitation rate was calculated as $\mathrm{E}=\mathrm{F} / \mathrm{Z}$. The length at first capture " $\mathrm{L}_{\mathrm{c}}$ " was determined from the catch curve according to Pauly (1984a \& b).

The relative yield per recruit $(\mathrm{Y} / \mathrm{R})^{\prime}$ and relative biomass per recruit $(\mathrm{B} / \mathrm{R})^{\prime}$ were 
estimated by using the model of Beverton and Holt (1966) modified by Pauly and Soriano (1986) and incorporated in the FISAT software package as follows;

$$
\begin{aligned}
& (\mathrm{Y} / \mathrm{R})^{\prime}=\mathrm{E} \mathrm{U} \mathrm{M}^{\mathrm{M} / \mathrm{K}}\left[1-(3 \mathrm{U} / 1+\mathrm{m})+\left(3 \mathrm{U}^{2} / 1+2 \mathrm{~m}\right)-\left(\mathrm{U}^{3} / 1+3 \mathrm{~m}\right)\right] \\
& (\mathrm{B} / \mathrm{R})^{\prime}=(\mathrm{Y} / \mathrm{R})^{\prime} / \mathrm{F}
\end{aligned}
$$

Where $(Y / R)^{\prime}$ is the relative yield per recruit,

$(\mathrm{B} / \mathrm{R})^{\prime}$ is the relative biomass per recruit,

$\mathrm{M}$ is the natural mortality coefficient,

$\mathrm{F}$ is the fishing mortality coefficient,

$\mathrm{K}$ is the growth parameter,

$\mathrm{E}$ is the exploitation rate or the fraction of deaths caused by fishing, $\mathrm{m}=(1-\mathrm{E}) /$ $(\mathrm{M} / \mathrm{K})=\mathrm{K} / \mathrm{Z}$ and $\mathrm{U}=1-\left(\mathrm{L}_{\mathrm{c}} / \mathrm{L}_{\infty}\right)$.

\section{RESULTS}

\section{Catch characteristics}

A total number of 1168 fish were collected from the catch of trammel nets working at four stations from River Nile at Aswan. It was found that O. niloticus represented the majority of catch composition by more than $88 \%$ of numerical abundance and the rest proportion was $T$. zillii. O. niloticus ranged in total length from $13.5 \mathrm{~cm}$ to $24.5 \mathrm{~cm}$ and showing a modal length at $15.5 \mathrm{~cm}$ at most of the stations. While, T. zillii ranged between $12.5 \mathrm{~cm}$ and $18.5 \mathrm{~cm}$ in total length exhibiting a modal length of $14.5 \mathrm{~cm}$ (Fig. 2).
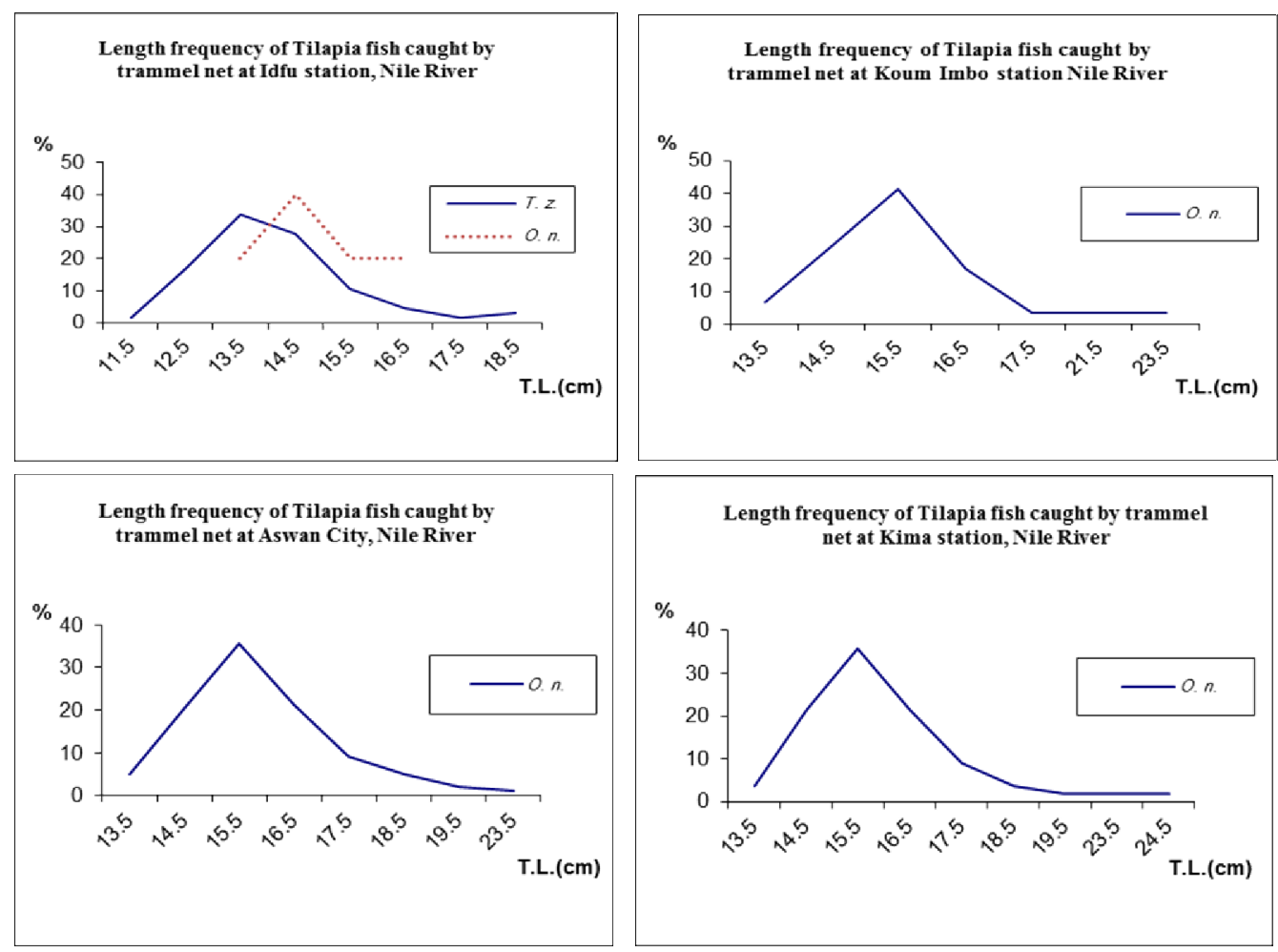

Fig. 2: Length frequency distributions of tilapia fish sampled from four stations at Aswan Governorate (2008).

The length frequency distribution curves (Fig. 2) of fish caught by trammel nets revealed uni-modal asymmetrical curves positively skewed at the right hand side due to entanglement effect for large sized fishes. 
Von Bertalanffy's growth parameters were estimated as $L_{\infty}=25.73 \mathrm{~cm}$ (asymptotic length); $k=0.73$ year $^{-1}$ for $O$. niloticus and $L_{\infty}=19.43 \mathrm{~cm} ; \mathrm{k}=1.4$ year ${ }^{-1}$ for Tilapia zillii.

\section{Mortality}

The annual instantaneous rate of total mortality $(\mathrm{Z})$ for $O$. niloticus as estimated from the length converted catch curve was 3.64 (Fig. 3). The solid line shows the regression equation fitted to data for length converted catch curve. The lengths for small ages (left hand side) showing ascending line were excluded as those don't represent fully exploited groups. The last two length groups (right hand side) were also excluded due to insufficient number of individuals represented.

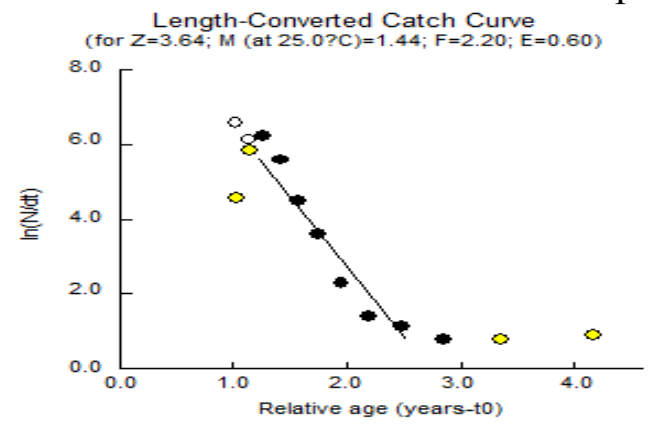

Fig. 3: Length converted catch curve of O. niloticus, Aswan, River Nile

The annual instantaneous rate of natural mortality (M) derived from the Pauly's empirical formula was 1.44. The average water temperature (used in the formula) was used as $25^{\circ} \mathrm{C}$ according to Elewa and Latif (1988) and in the mean time as an average between $24{ }^{\circ} \mathrm{C}$ (El-Shahat, 2000) and $26{ }^{\circ} \mathrm{C}$ (Bishai et al., 2000). The calculated annual instantaneous rate of fishing mortality (F) was 2.20. The current exploitation (E) was estimated as 0.60 indicating a state of over exploitation (Table 1).

Table 1: Mortality and exploitation rates of O. niloticus and T. zillii caught from Aswan region, River Nile.

\begin{tabular}{|c|c|c|c|c|c|c|c|c|}
\hline \multirow{2}{*}{ species } & $\mathbf{L}_{\infty}$ & $\mathbf{K}$ & $\mathbf{Z}$ & $\mathbf{M}$ & $\mathbf{F}$ & $\mathbf{I n p u t}$ parameters & \multirow{2}{*}{$\mathbf{E}_{\text {current }}$} \\
\cline { 7 - 9 } O. niloticus & 25.73 & 0.73 & 3.64 & 1.44 & 2.20 & $\mathbf{M} / \mathbf{K}$ & $\mathbf{L}_{\mathbf{c}} / \mathbf{L}_{\infty}$ & \\
\hline T. zillii & 19.43 & 1.40 & 5.60 & 2.38 & 3.22 & 1.700 & 0.548 & 0.60 \\
\hline
\end{tabular}

The total mortality coefficient (Z) of T. zillii was estimated as $5.60 \mathrm{y}^{-1}$. While its natural mortality rate $(\mathrm{M})$ was computed as $2.38 \mathrm{y}^{-1}$ and the fishing mortality rate was $3.22 \mathrm{y}^{-1}$ (Fig. 4).

The exploitation rate (E) was found to be $0.57 \mathrm{y}^{-1}$ as shown at Table (1).

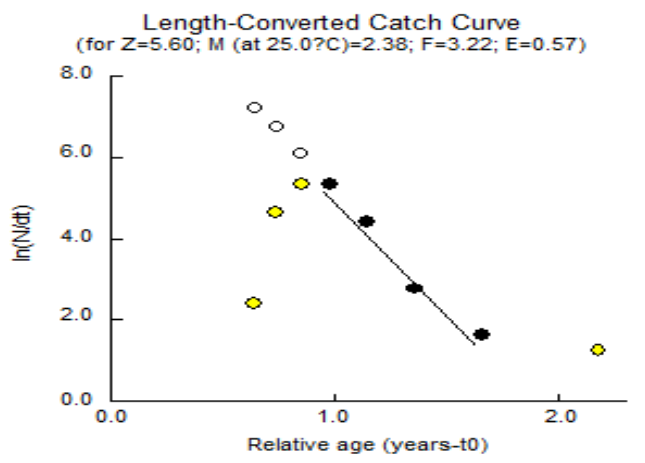

Fig. 4: Length converted catch curve of T. zillii, Aswan, River Nile 


\section{Probability of capture}

From the length converted catch curve, extrapolation of a regression line drawn was used to approximate the probability of capture for each length group which was then used to estimate the selection (probability) parameters based on the extrapolated points (Gayanilo et al. 1997). The probability of capture was plotted using the running average technique to estimate the selection parameters. The length at first capture $\left(\mathrm{L}_{\mathrm{c}}\right)$ at which $50 \%$ of the fish that become vulnerable to capture was estimated to be $14.11 \mathrm{~cm}$ and $13.41 \mathrm{~cm}$, for $O$. niloticus and T. zillii, respectively (Table 2 \& Figs. 5 \& 6).

Table 2: Estimated sizes at 25, 50 and $75 \%$ probability of capture of O. niloticus and T. zillii at Aswan region

\begin{tabular}{|c|c|c|}
\hline Species & O.niloticus & T. zillii \\
\hline $\mathbf{L}_{\mathbf{2 5}} \mathbf{( c m )}$ & 13.31 & 12.65 \\
\hline $\mathbf{L}_{\mathbf{5 0}} \mathbf{( c m )}$ & 14.11 & 13.41 \\
\hline $\mathbf{L}_{\mathbf{7 5}} \mathbf{( c m )}$ & 14.91 & 14.25 \\
\hline
\end{tabular}

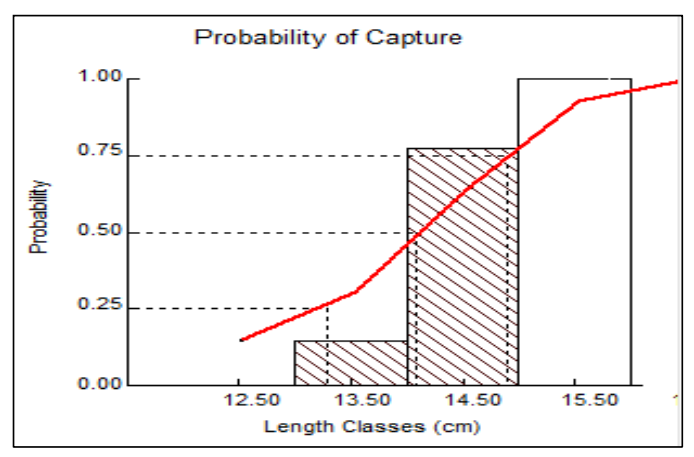

Fig. 5: Probability of length at first capture for O. niloticus, River Nile, Aswan

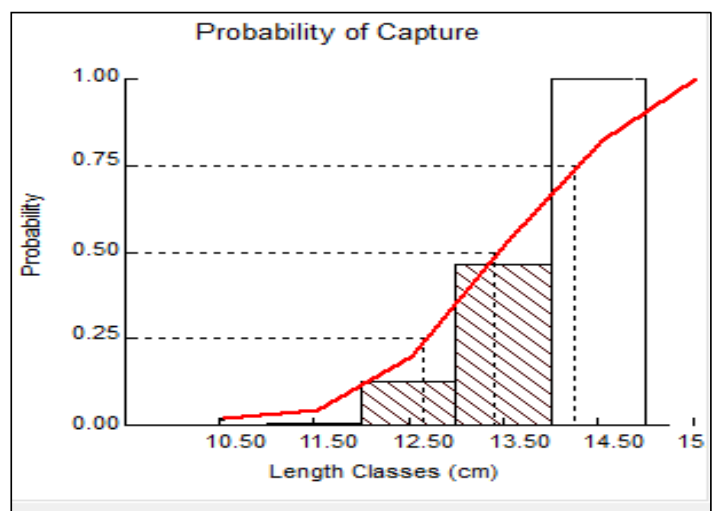

Fig. 6: Probability of length at first capture for T. zillii, River Nile, Aswan

A narrow selection range $\left(\mathrm{L}_{75}-\mathrm{L}_{25}\right)$ was found to be $1.6 \mathrm{~cm}$ for both of the two species. Fish were fully recruited to the fishery $\left(\mathrm{L}_{100}\right)$ at sizes of $15.71 \mathrm{~cm}$ and 15.04 $\mathrm{cm}$ for the two species respectively.

\section{Yield per Recruit}

The relative yield-per-recruit $\left(\mathrm{Y}^{\prime} / \mathrm{R}\right)$ of $O$. niloticus was determined as a function of $\mathrm{L}_{\mathrm{c}} / \mathrm{L}_{\infty}$ and $\mathrm{M} / \mathrm{K}$ (Table 3 and Fig. 7). The current exploitation $(\mathrm{E}=0.60)$ of population obtained by trammel nets was lower than the maximum allowable limit based on yield-per-recruit calculation $\left(\mathrm{E}_{\max }=0.877\right)$, which leads to the maximum sustainable yield (MSY), and at the same time the current exploitation was lower than the optimum exploitation rate $\left(\mathrm{E}_{\mathrm{opt}}=0.757\right)$. 


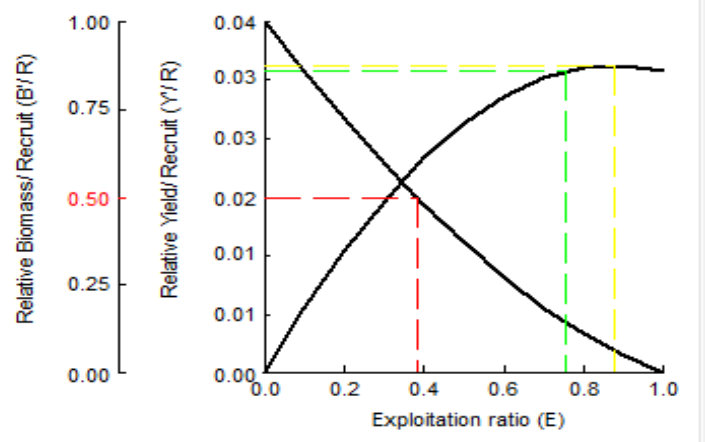

Fig. 7: Relative yield per recruit (Y/R)' and biomass per recruit (B/R)' of O. niloticus, River Nile, Aswan

On the other hand, the current exploitation rate of T. zillii $(\mathrm{E}=0.57)$ was also lower than the maximum limit $\left(\mathrm{E}_{\max }=0.749\right)$ and lower than the optimum rate $\left(\mathrm{E}_{\mathrm{opt}}=\right.$ 0.657) (Table 3 and Fig.8).

Table 3: Relative exploitation parameters for O. niloticus and T. zillii caught at Aswan region.

\begin{tabular}{|c|c|c|}
\hline \multirow{2}{*}{ Exploitation parameter } & \multicolumn{2}{|c|}{ Species } \\
\cline { 2 - 3 } & O. niloticus & T. zillii \\
\hline $\mathbf{E}_{\mathbf{1 0 ( o p t . )}}$ & 0.757 & 0.657 \\
\hline $\mathbf{E}_{\mathbf{5 0}}$ & 0.381 & 0.396 \\
\hline $\mathbf{E}_{\max }$ & 0.877 & 0.749 \\
\hline
\end{tabular}

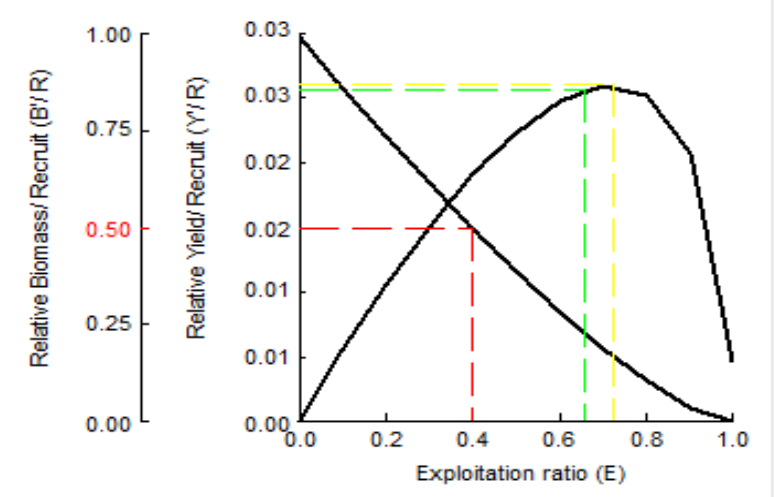

Fig. 8: Relative yield per recruit (Y/R)' and biomass per recruit (B/R)' of T. zillii, River Nile, Aswan.

\section{DISCUSSION}

It was found that only the two species Oreochromis niloticus and Tilapia zillii dominated the catch of the trammel nets at Aswan region. This may return to the method of fishing and the design characteristics of surface catching trammels and (or) to the lowered fish diversity which is a good indicator of a stressed ecosystem (Leveque, 1995) and it was commonly agreed that the higher the fish diversity, the more stable the fish community (Albarat and Lae, 2003; Emmanuel and Onyema, 2007).

The modal length of $O$. niloticus was larger where wider inner layers (2.9 - 3.0 $\mathrm{cm}$ mesh bar) are used in the construction of trammel nets at Kima, Aswan city and 
Koum Imbu. While that of $T$. zillii was lower due to smaller mesh sizes used in trammel nets $(2.7-2.8 \mathrm{~cm})$ at Idfu (Fig. 3).

Similar studies revealed that $O$. niloticus and $T$. zillii dominated the catch by more than $51 \%$ and $36 \%$ respectively at Rosetta branch of River Nile at Kafr ElZaiat and Desouq (Hatem and Mazrouh, 2008).

Estimation of growth and mortality parameters are used as input variables for bio-demographic models to characterize the state of various fish populations. Growth parameter $(\mathrm{K})$ as estimated from length frequency analysis (ELEFAN I) was $0.73 \mathrm{y}^{-1}$ for $O$. niloticus and $1.4 \mathrm{y}^{-1}$ for $T$. zillii. These values were higher than those estimated by Hatem and Mazrouh (2008) at Rosetta branch and may return to a manifestation of the observations that similar species experience different growth rates in different habitats (Lowe - McConnell, 1982).

The estimated total mortality coefficients $(Z)$ as well as both of the natural mortality (M) and fishing mortality (F) coefficients for O. niloticus and T. zillii, were higher than those estimated by Hatem and Mazrouh (2008) at Rosetta branch of the River Nile indicating that the two species are subjected to high mortality levels. Beverton and Holt (1956) pointed out that the natural mortality coefficient is directly related to the growth coefficient $(\mathrm{K})$ and inversely related to the asymptotic length $\left(\mathrm{L}_{\infty}\right)$ and the life span longevity. Hence, T. zillii exhibiting higher growth rate (1.4) and lower asymptotic length $(19.43 \mathrm{~cm})$ undergoes higher natural mortality $(\mathrm{M}=2.38$ $\left.\mathrm{y}^{-1}\right)$. The reverse is true for $O$. niloticus.

The current exploitation rates (E) were found to be 0.60 as in case of $O$. niloticus and 0.57 for T. zillii. According to Gulland (1971) the fishing mortality should equal to the natural mortality resulting in a fixed and optimal exploitation rate $(0.50)$ to reach and ensure a sustainable yield. Therefore, it is worth mentioning that the fishing mortality which reflects the fishing effort far exceeds the natural mortality rate for the both species.

As suggested by Beverton and Holt (1959), The $\mathrm{M} / \mathrm{K}$ ratios obtained in the present study were well within the normal range of $1-2.5$. As a rule the $\mathrm{Z} / \mathrm{K}$ ratio of 1.0 is considered as growth dominated and if it is more than 2, then it is mortality dominated (Al-Qishawe et al., 2014). In the present study, it was equal 4.986 and 4.0 for the two species studied respectively, which showed that the fishery of $O$. niloticus and T. zillii was mortality dominated.

In Lake Nasser, Khalifa et al. (2000) found that the exploitation rate of $O$. niloticus equals to 0.80 and as a result the species was heavily exploited.

Length at first capture $\left(\mathrm{L}_{\mathrm{c}}\right)$ was estimated to be 14.11 and $13.41 \mathrm{~cm}$, for $O$. niloticus and $T$. zillii, respectively. The differences can be attributed to the differences of the mesh sizes of nets used where wider meshes were used for O. niloticus catching trammels while smaller meshes were observed for those of $T$. zillii. However, the same narrow selection range was observed due to different varieties according to several characteristics of net and fish (Fujimori and Tokai, 2001).

Several values of length at first capture $\left(\mathrm{L}_{\mathrm{c}}\right)$ ranging from $12 \mathrm{~cm}$ to $17 \mathrm{~cm}$ were run against optimum and maximum exploitation rates to find out the length at which maximum relative per recruit $\left(Y^{\prime} / R\right)$ could be obtained. The results revealed that the $\left(\mathrm{Y}^{\prime} / \mathrm{R}\right)$ gradually increased within $\mathrm{L}_{\mathrm{c}}$ increase up to the length $15 \mathrm{~cm}$ at which the maximum $\left(Y^{\prime} / \mathrm{R}\right)$ could be achieved. However, the levels dropped down with any further increase in $\mathrm{L}_{\mathrm{c}}$ beyond $15 \mathrm{~cm}$ indicating that this length is the optimum length at first capture to maintain the sustainable exploitation of O. niloticus in Aswan area. Similarly, $\mathrm{L}_{\mathrm{c}}$ value for $T$. zillii was found at $13 \mathrm{~cm}$ where maximum yield/recruit was 
reached and remained stable till the length $15 \mathrm{~cm}$ and afterwards decreased with further increasing in $\mathrm{L}_{\mathrm{c}}$ values.

Raising $\mathrm{L}_{\mathrm{c}}$ values to $15 \mathrm{~cm}$ will lead to gaining an extra-weight as reported by Hatem and Mazrouh (2008) that the maximum annual increments in weight were observed at (such length) the end of the third year of life for O. niloticus.

As obvious from Relative yield per recruit (Y/R) and relative biomass per recruit $(\mathrm{B} / \mathrm{R})^{\prime}$ Figures 4 and 5, it is evident that the optimum exploitation level $\left(\mathrm{E}_{\mathrm{opt} .}=\right.$ $0.757)$ as well as the maximum one $\left(\mathrm{E}_{\max .}=0.877\right)$ are higher than the current exploitation rate $(\mathrm{E}=0.60)$ of $O$. niloticus. The same trend was observed for $T$. zillii where its current exploitation level (0.57) is smaller than both the optimum (E opt. $=$ $0.657)$ and the maximum value $\left(\mathrm{E}_{\text {max. }}=0.749\right)$. At the same time, they exeeded the optimum value (0.50) as suggested by Gulland (19971). Therefore, the recent fishing effort should be reduced. On the other hand, the fishing nets especially trammel nets should be kept at mesh size $30 \mathrm{~mm}$ mesh bar for the inner net to attain sizes of $15 \mathrm{~cm}$ as an optimum size.

\section{CONCLUSION}

Results indicated that the stock of $O$. niloticus and T. zillii at Aswan region are overexploited. Although the current exploitation rate is lower than the optimum one for the both species, they exhibit a mortality dominated status due to the removal of pre - spawner fishes. Therefore, it is very important to raise the mesh sizes of the inner layer of trammel nets to at least $3 \mathrm{~cm}$ mesh bar to cope with catching an optimum size of $15 \mathrm{~cm}$ for both of $O$. niloticus and $T$. zillii for getting the maximum yield per recruit and to spawn at least once during their lifespan at the area of study. This will affectively reduces the risk of a stock collapse by a long-term increase of the spawning stock size of tilapia fish and substantially support the sustainable exploitation of these fishes.

\section{ACKNOWLEDGMENT}

I am greatly indebted to the anonymous referees for their valuable comments and criticism.

\section{REFERENCES}

Abd El-Azim, M.E. (1974). Biological studies on Tilapia nilotica and T. galilaea in Lake Nasser. M. Sc. Thesis, Fac. Sci., Alex. University.

Abd El-Aziz, E.H.; Ezzat, A.A. and El-Bassir, M.A. (1990). Growth assessment of Cichlid fish (Oreochromis niloticus, L.) from the Egyptian and Sudanese inland waters. Proc. Int. Symp. Biol. and Cul. Tilapias, Alex., 255 - 291.

Abd El-Baky, T. E. and El-Serafy, S. S. (1990). Length weight relationship and relative condition factor of three species of cichlid fishes inhabiting Lake Manzalah, Egypt. Egypt. J. Aqua. Res., 16(1): 147 - 169.

Abd-Alla, A. and K. M. Talaat (2000). Growth and dynamics of tilapias in Edku Lake, Egypt. Bull. Inst. Oceanog. Fish., A.R.E., 26: 183 - 196.

Adam, H. A. (2000). Age and Growth of Oreochromis niloticus L. and Sarotherodon galilaeus Art. p.83-84. In J.F. Craig (ed.) Sustainable fish production in Lake Nasser: ecological basis and management policy. ICLARM Conf. Proc. 6 1: I84p. 
Adam, E.A. (2004). Stock assessment of some important commercial fish species of Lake Nasser, Egypt. Ph.D. Thesis, Fac. Sci., Assiut. Univ., Egypt.

Akel, S.K. (1989). Effect of water pollution on Tilapia population in Lake Mariut. M.Sc. Thesis Fac. Sci., Alex., Univ. 211p.

Albaret, J.J. and Lae, R. (2003). Impact of Fishing on Fish Assemblages in tropical lagoons, the example of the Ebrie Lagoon, West Africa. Aquat. Living Resour, 16: 1-9.

Al-Qishawe, Mona M. S., Thamer S. Ali and Asma A. Abahussain (2014). Stock assessment of white spotted rabbitfish (Siganus canaliculatus Park, 1797) in Jubail marine wildlife sanctuary, Saudi Arabia. Intern. J. Fish. Aquat. Stud., 1(6): 48-54.

Bakhoum, S.A. (1994). Comparative study on length-weight relationship and condition factor of genus Oreochromis in polluted and non-polluted parts of Lake Mariut, Egypt. Egypt. J. Aqua. Res., 20(1): 201 - 210.

Bakhoum, S.A. (1995). The food and feeding ecology of Oreochromis niloticus (Linn) and Oreochromis aureus (Steind.) in Lake Mariut, Egypt. Alex. Sci. Exch., 16(1): 71 - 85.

Bakhoum, S.A. (2002). Comparative reproductive biology of the Nile Tilapia Oreochromis niloticus (L.), Blue Tilapia, Oreochromis aureus (Steind.) and their hybrids in Lake Edku, Egypt. J. Aquat. Biol. and Fish, 6(3): 121 - 142.

Bayoumi, A.R. and Khalil, M.T. (1988). Tilapia fisheries in lake Manzalah, Egypt. Egypt. J. Aqua. Res., 14 (3): 87 - 99.

Beverton, R. J.H. and Holt, S. J. (1956). A review of methods for estimating mortality rates in exploited fish populations, with special reference to sources of bias in catch sampling. Rapp. P.- v. Réun. CIEM 1956; 140:67 - 83.

Beverton, R.J.H. and Holt, S.J. (1959). A review of the life-spans and mortality rates of fish in nature and their relation to growth and other physiological characteristics. In: GEW. Wolstenholme, MO. Connor (eds.), CIBA Found. Colloq. on Ageing 1959; 5:142-80.

Beverton, R. J. H. and Holt, S. J. (1966). Manual of methods for fish stock assessment. Part 2. Tables of yield functions. FAO Fish. Tech. Pap./FAO Doc.(38) Rev.1 : 67 p.

Bishai, H. M.; Samir A. Abdel-Malek and Magdy T. Khalil (2000). Lake Nasser. A Treatise. Publications of National Biodiversity Unit. No. 11, Egypt.

El-Bokhty, E. E. B. (2006). Assessment of family Cichlidae inhabiting Lake Manzala, Egypt. Egyptian Journal of Aquatic Biology \& Fisheries, 10: 85-106.

El-Bokhty, E. E. B. and A. M. El-Far (2014). Some fishery aspects of Nile tilapia, Oreochromis niloticus at Rosetta Branch of the River Nile, Egypt. Egypt. J. Aquat. Biolo. Fish., (Accepted paper).

Elewa, A. S. and A. A. Latif (1988). Effect of physicochemical conditions on the deposition of some elements of Aswan High Dam reservoir water. Bull. Inst. Oceangr. \& Fish., ARE , 14(3):189 - 212.

El-Haweet, A.A. (1991). Biological studies of some cichlid species in Lake Borollus. M.Sc. Thesis. Fac. Sci., Alex. University.

El-Sayed, H. K. and Moharram, S. G. (2007). Reproductive biology of Tilapia zillii (GERV, 1848) from Abu Qir Bay, Egypt. Egypt. J. Aquat. Res., 33 (1): 379-394.

El-Shahat, M. M. (2000). Lake Nasser Overview. P. 3-6 In J. F. Craig (Ed.) Sustainable fish production in Lake Nasser: ecological basis and management policy. ICLARM Conf. Proc. 61, 184 p. 
El-Shazly, A.A. (1993). Biological studies on four Cichlid fishes (T. nilotica, T. galilae, T. zillii, T. aurea) in Lake Maruit. M.Sc. Thesis, Fac. Sci., Zagazig University.

Emmanuel, B.E. and Onyema, I.C. (2007). The plankton and fishes of a tropical creek in south-western Nigeria. Turk. J. Fish. Aquat. Sci. 7(2):105-113.

Eskander, A. (2004). Biological studies on the main Cichlid fishes of the Nozha Hydrodrome, Alexandria, Egypt. Ph.D. Thesis, Fac. Sci., Zagazig Univ., Egypt.

Essa, M.A. and Faltas, S.N. (1997). Impact of pollution problems on some fishery aspects of Tilapia in Lake Mariut basins, Egypt. Proceedings the $7^{\text {th }}$ Internat. Conf. on Environ. Protect. Is a must, Alex., Egypt. 419 - 441.

Fujimori, Y. and Tokai, T. (2001). Estimation of gillnet selectivity curve by maximum likelihood method, Fisheries Science, 67(4): 644-654.

GAFRD (2002-2009). The General Authority of Fish Resources Development, Year Book of Fishery Statistics, Cairo, Egypt.

Gayanilo, F. C. Jr., P. Sparre, and D. Pauly (1997). The FAO-ICLARM Stock Assessment Tools (FiSAT). FAO Computerized Information Series (Fisheries). No. 8 Rome, FAO.

Gulland, J. A. (1971). The fish resources of the Ocean. West Byfleet, Surrey, Fishing News (Books), Ltd., for FAO, 255 p.

Ishak, M.M.; Al-Sayes, A.A. and Talaat, K.M. (1985). Tilapia fisheries in Lake Borollus, Egypt. Kuwait Bull. Sci. Res., (6): 225 - 242.

Khalifa, U. S. A., M. Z. Agaypi, and H. A.A dam (2000). Population dynamics of Oreochromis niloticus L. and Sarotherodon galilaeus Art. 90-97. In: Sustainable Fish Production in Lake Nasser: Ecological Basis and Management Policy. J. F. Craig (ed.) ICLARM Con. Proc., 61:184 p.

Khallaf, E. A. (2002). An ecological assessment of Bahr Shebeen Nilotic Canal (A Review Paper, presented at the 9th International Conference, 1-6 September, 2002, Aleppo University, Syria). Journal Union Arab Biolology, 17: 65-75.

Khallaf, E. A.; M. Galal, and M. Authman (2000). The biology of Oreochromis niloticus in a polluted canal. In the International Congress on the Biology of Fish. 20-23 July 2000, University of Aberdeen, Scotland, UK. Pp: 17.

Leveque, C. (1995). Role and consequence of fish diversity in the functioning of African freshwater ecosystems: a review. Aquat. Living Resour. 8: 59-78.

Lowe-MacConnel, R.H. (1982). Tilapias in Fish Communities. P 83 - 113. In: Pullin, R.S.V and Lowe-McConnell, R.H, (Editors). The biology and culture of tilapis. ICLARM Conference Proceedings 7, 432 p. International Center for Living Aquatic Resources Management, Manilla, Philippines.

Mahmoud, H. Hatem and Mazrouh, M. Marwa (2008). Biology and Fisheries Management of Tilapia Secies in Rosetta Branch of the River Nile , Egypt. Egypt. J. Aquat. Res., Vol. 34, Special Issue, 2008.

Mehanna, S.F. (2005). Population dynamics and management of the Nile tilapia Oreochromis niloticus in Wadi El-Raiyan Lakes, Egypt. African J. Biol. Sci., 1 (1): $79-88$.

Pauly, D. (1980). The inter relationships between natural mortality, growth parameters and mean environmental temperature in 175 fish stocks. J. Con. Int. Explor. Mer. 39 (2):175 - 192.

Pauly, D. (1983). Some simple methods for assessment of tropical fish stocks. FAO Fish. Tech. Pap., 234-252 p.

Pauly, D. (1984a). Length-converted catch curves. A powerful tool for fisheries research in the tropics. Part 1. ICLARM Fishbyte, 1 (2): 9-13 . 
Pauly, D. (1984b). Recent developments in the methodology available for the assessment of exploited fish stocks of reservoirs. In Status of African reservoir fisheries. CIFA Tech. Pap. (10): 326 pp. Ed. By Kapatasky, J. M. and T. Petr.

Pauly, D. and M. L. Soriano (1986). Some practical extensions to Beverton and Holt's relative yield- per- recruit model. In The first Asian Fisheries Forum, Eds., Maclean, J. L., L. B. Dizon and L. V. Hosillo, pp: 491-496.

Talaat, K.M. (1979). Application of some growth models on Tilapia population in Lake Nasser and some other area of Egyptian inland water. M.Sc. Thesis, Fac. Sci., Alex. Univ.

Wetherall, J. A. (1986). A new method for estimating growth and mortality parameters from length-frequency data. ICLARM Fishbyte, 4(1): 12-14.

\footnotetext{
ARABIC SUMMARY

$$
\begin{aligned}
& \text { تقييم مصايد البلطي النيلى و البلطى الأخضر الناتج من منطقة أسوان - نهر النيل - مصر }
\end{aligned}
$$

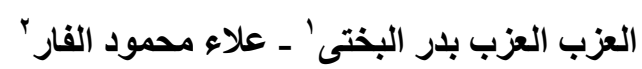

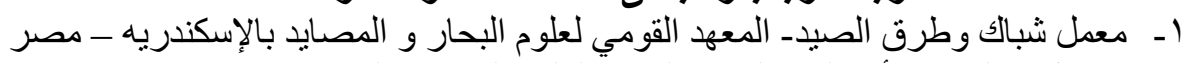

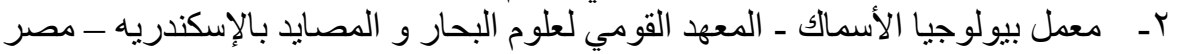$$
\text { تم دراسة اسماك البلطى السائدة فى منطقة أسوان - نهر النيل الناتجه من الصيد التجارى ضمن دراسه }
$$

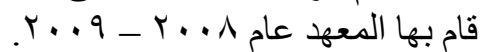$$
\text { اظهر التحليل النوعى لمصيد أسماك البلطى ان البلطى النيلى هو الأكثر تواجدا يليه البلطى الأخضر و }
$$

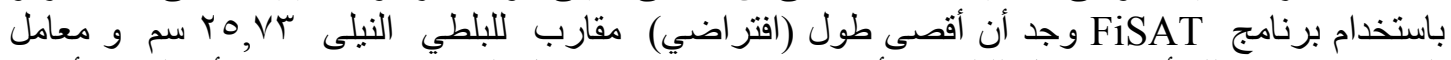

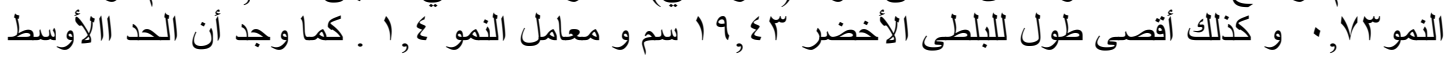

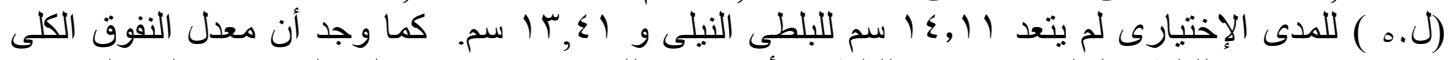

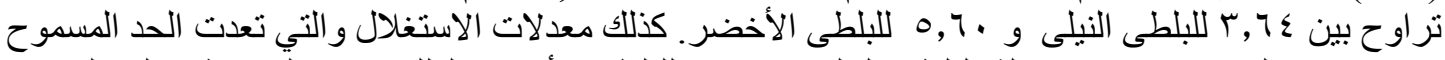

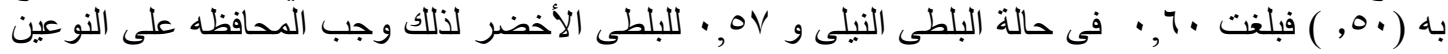

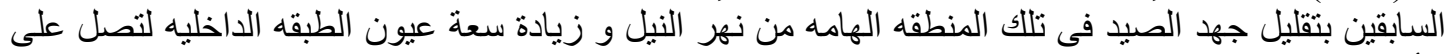

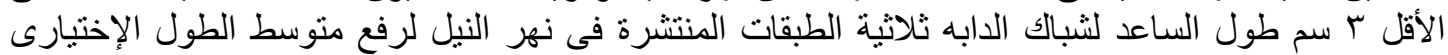

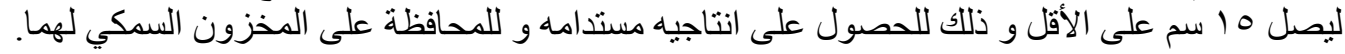

